\title{
Re-Framing the Sharia Arbitration Debate
}

\author{
Trevor C.W. Farrow ${ }^{*}$
}

\author{
Dear Mr. McGuinty: \\ An important tenet of Canadian democracy \\ hangs in the balance of your response to the \\ matter of religious arbitration in the province \\ of Ontario. ${ }^{1}$
}

\section{Introduction}

The "matter of religious arbitration in ... Ontario" to which Margaret Atwood and nine others are referring is a vocal, polarized debate the "[S]haria debate." It has largely been framed by two questions. Should Ontario "[p]rohibit the use of religion in the arbitration of family law disputes" 3 to avoid "the ghettoization of members of religious communities as well as human-rights abuses?"4 Or would such a prohibition do a "great disservice to a number of religious groups in Ontario, and nothing to safeguard the interests of Muslim women?"5 Several fundamental rights and interests are engaged by this debate, including religious freedom, gender equality, the rights of children, national and cultural identity, freedom from hatred, the role of the state in family law, and others.

Because the stakes involved in this debate are high, this debate has captured the interest of many sectors of civil society. It has also captured the interest of the Ontario government, which has recently passed legislation on the issue. ${ }^{6}$ While this issue is clearly important and should be addressed, ${ }^{7}$ there are three problems with the way in which it has framed - and confused - the specific arbitration context of the debate.
First, the issue is not about simply prohibiting religious tribunals. Second, it is not only an Ontario issue. Third, it is not necessarily even a Sharia (or religion) issue. This article focuses on these three problems.

\section{Dispute Resolution and Religion}

In Ontario, Jews, Christians, Muslims, and others have engaged in religious-based dispute resolution processes for years. ${ }^{8}$ However, a public debate about whether Sharia law should be used in family disputes in Ontario commenced in 2003 after the announcement of the creation of the Islamic Institute of Civil Justice (IICJ). The IICJ stated that it planned to establish a Darul-Qada - judicial tribunal - to conduct arbitrations in Ontario according to Islamic law. ${ }^{9}$

In June 2004, following the IICJ announcement, former Ontario Attorney General Marion Boyd was given a mandate by the Ontario government to look into and make recommendations on the issue of family law and arbitration in Ontario, including religiousbased arbitrations. ${ }^{10}$ Her report was released in December 2004. In it, she essentially recommended the continuation of arbitrations in the context of family law, including regulated religious-based arbitrations. ${ }^{11}$ From the time of the IICJ announcement, through the release of the Boyd Report and certainly for most of the following year, the public debate surrounding these issues escalated. Those in favour ${ }^{12}$ and 
those opposed ${ }^{13}$ to the use of Sharia law in family disputes actively debated their positions in the media, ${ }^{14}$ at the bar, ${ }^{15}$ and in the academy. ${ }^{16}$ Finally, in September 2005, after witnessing the public debate and reviewing the Boyd Report, the Ontario government announced that it did not plan to follow Boyd's recommendations. ${ }^{17}$ Ontario Premier Dalton McGuinty told the Canadian Press that there "will be no Sharia law in Ontario" and, further, that there "will be no religious arbitration in Ontario."18 Notwithstanding that, for years, faith-based arbitrations had been conducted in accordance with numerous religious practices, the Premier decided to abolish "religious arbitration in Ontario." 19 It was this decision that ultimately led to the February 2006 enactment of Ontario's Family Statute Law Amendment Act. ${ }^{20}$

While the Ontario Premier's intention is to prohibit religious arbitrations in Ontario (at least those not conforming to Canadian law), this intention will likely not materialize, despite the new legislation. There are legal and practical impediments to prohibiting faithbased arbitrations altogether. The primary legal impediment consists of constitutional protections, including protections for freedom of religion and others. ${ }^{21}$ The thorny Charter implications of the Premier's initial statement likely led Ontario's Attorney General, the Hon. Michael Bryant, to make an important but more modest announcement. Prior to the drafting of the recent legislation, the Attorney General announced that the Ontario government "will ensure that the law of the land in Ontario is not compromised, that there will be no binding family arbitration in Ontario that uses a set of rules or laws that discriminate against women." 22

Moreover, as a practical matter, religious tribunals will not be abolished because the government is not typically in the business of regulating and policing the private religious affairs of Ontario residents. As Marion Boyd stated, Sharia arbitration "will happen in mosques and community centers and it will just happen." 23 Similarly, Mubin Sheikh, a member of the Masjid-al-Noor mosque in Toronto commented: "Is the government going to stand outside every mosque and ask if people are going in to do faith-based arbitration? No... A A ban will change nothing.'" 24

So, as I stated in the introduction to this article, one problem with the Sharia debate as it has been framed is that it is not about simply prohibiting religious tribunals. What is at stake, rather, is whether the state will sanction, or defer to, decisions of a faith-based dispute resolution panel operating within its jurisdiction. In Ontario, this deferral process is provided for in the Arbitration Act, $1991 .{ }^{25}$ Under that statute, parties to essentially any dispute can subject their proceeding to its provisions provided the dispute is not "excluded by law." ${ }^{26}$ Parties choose arbitration because of its many benefits, including the choice of decision-maker, process, pace, and of course, privacy. ${ }^{27}$ To the extent that parties agree to subject their arbitration to the parameters of the Arbitration Act, the courts retain very limited power to review the result of that arbitration. ${ }^{28}$ As a result, the parties are in large measure bound by the result. ${ }^{29}$ The legitimacy of this regime has been fully recognized by the courts. For example, when referring generally to arbitration, Supreme Court of Canada Justice LeBel stated that it is, "in a broader sense, a part of the dispute resolution system the legitimacy of which is fully recognized by the legislative authorities." ${ }^{30}$

The first question in the debate, therefore, needs to be kept technically clear: does the jurisdictional reach of a provincial statute - i.e., an arbitration statute - include family disputes resolved pursuant to faith-based laws that do not conform to Ontario or Canadian laws, which would in turn require a provincial superior court to defer to an arbitral decision regarding such a dispute? On this question the Ontario government - in its new legislation - clearly says no (thereby disagreeing with the recommendations in the Boyd Report $\left.{ }^{31}\right)$. According to section 2.2(1) of the recent Family Statute Law Amendment Act:

When a decision about a matter described in clause (a) of the definition of "family arbitration" in section 1 is made by a third 
person in a process that is not conducted exclusively in accordance with the law of Ontario or of another Canadian jurisdiction,

(a) the process is not a family arbitration; and

(b) the decision is not a family arbitration award and has no legal effect. ${ }^{32}$

Legislating that a religious family arbitration not conducted in accordance with Ontario or Canadian law is "not a family arbitration" and, further, that such arbitration "has no legal effect" under Ontario law is clearly different from the project of prohibiting religious tribunals altogether. Even if the result of the new legislation is essentially to exclude religious tribunals (employing various non-Ontario or non-Canadian legal regimes) from taking advantage of Ontario arbitration legislation, it would be virtually impossible for a province to prohibit altogether (or police) the practice of private faith-based dispute resolution.

Given that the new legislation contemplates the drafting of regulations designed to govern the details of the arbitration process, how the new legislation will work and the differences it will make are largely still open questions. ${ }^{33}$ In any event, while I am in favour of the new legislation, both in the immediate context of family law protections and more broadly as a signal that we should be concerned about public interest values that get dealt with behind the veil of private arbitration, ${ }^{34}$ we need to be clear about what is, and what is not, at stake in this debate.

\section{A National Issue}

Second, we should also be clear that while the debate has been largely focused on Ontario, it is certainly not limited to Ontario (as evidenced by the 8 September 2005 protests about Sharia-based tribunals that occurred in cities internationally ${ }^{35}$ ). As Atwood and others have commented, the "eyes of the world are quite literally watching." ${ }^{36}$ Canadians across the country have joined the worldwide protests against Sharia tribunals. As reported by Sheldon Gordon, "Developments in Ontario are already reverberating elsewhere in Canada." ${ }^{37}$
This national and international interest has obviously stemmed from the fundamental gender, religious, and cultural questions at play in the debate. Equally crucial, and it is again an important reason for being accurate in this debate, is that any jurisdiction - whether Canadian or international - that has arbitration legislation similar to Ontario's Arbitration Act will potentially be facing the same dispute resolution issues. ${ }^{38}$ Therefore, it is important not to limit the potential reach of this debate, notwithstanding a late 2005 poll in which a majority of Canadians felt that faith-based arbitration should not be used to resolve family disputes. ${ }^{39}$

Alberta, for example - where the discussion in this article was first presented and where the "[Sharia] debate has barely begun" 40 - has arbitration legislation ${ }^{41}$ that provides for a very similar dispute resolution landscape to that provided by Ontario's Arbitration Act (except for the recent Family Statute Law Amendment Act amendments). In British Columbia, even though the provincial government announced that it has "no plans to .... change the laws .... to give any special recognition to any set of religious laws," ${ }^{2}$ there has been at least some interest expressed in formalizing the use of Sharia law in statesanctioned arbitration proceedings. ${ }^{43}$ As it stands now, British Columbia's Commercial Arbitration Act leaves room for disputes falling within its jurisdiction to be resolved according to Sharia law. ${ }^{44}$ Finally, given that the Uniform Arbitration Act ${ }^{45}$ forms the basis of much of the arbitration legislation that exists in Canada, this is clearly a national (and potentially international) issue. ${ }^{46}$

\section{Privatizing Civil Justice}

Third, and most fundamental, is the fact that - while the family law, gender, and cultural issues at stake are clearly important - the Sharia debate is really a red herring for something much bigger at play: the ongoing and systematic privatization of the Canadian public civil justice system. This third concern, in turn, involves a pair of sub-issues. One is that there is an increasing tendency to resolve important 
human rights and other public and private interest disputes behind closed doors without any kind of public scrutiny of the processes or results (Sharia or other). The other is that, as a result, we are systematically downloading privatizing - a fundamental tool of democratic governance. ${ }^{47}$

With respect to the withdrawal of dispute resolution from public scrutiny, the basic concern in the Ontario debate about arbitral tribunals employing Sharia law is that human rights under Sharia law are not adequately protected, particularly the rights of women and children. As summarized by the open letter to Dalton McGuinty by Margaret Atwood and others, quoted at the outset of this article, the concern is essentially that Sharia-based tribunals will lead to human rights abuses, "particularly for those who hold the least institutional power within the community, namely women and children." ${ }^{\text {48 }}$ Although I am certainly not an expert in Muslim law, my reading of the debate is that these concerns are justified. Moreover, they are important concerns that should be and at least in Ontario are being - addressed.

Unfortunately, as we have seen, almost any dispute (now excepting some family disputes in Ontario) can take advantage of current arbitration legislation and thereby, with the blessing of the state, exempt itself from the public civil justice system. At the same time, governments, courts, the bar, and industry are actively pushing the use of dispute resolution methods that are alternative to the public court system. These methods include, but are not limited to, processes governed by arbitration legislation. ${ }^{49}$ Therefore, an increasing number of commercial services disputes, employment disputes, pay-equity disputes, police complaints, family disputes, human rights disputes, etc. are being decided in private, using private adjudicators, without any of the procedural safeguards that are typically provided by our public court system. In this regard, it never ceases to amaze me that the public, while typically up in arms about the "activism" of our public judges, ${ }^{50}$ is largely silent (or ignorant) about the significant decisions made everyday by private decision-makers behind closed doors.
There is no doubt that many disputes lend themselves to these alternative processes. There is also no doubt that many of these disputes involve important public and private interest issues - often impacting upon the rights of individuals, including "those who hold the least institutional power within the community" ${ }^{1}$ that should be dealt with under the scrutiny of the public eye. ${ }^{52}$ Sharia panels, therefore, do not have a monopoly on potential state-sanctioned (or at least state-encouraged) human rights violations and other injustices resulting from private dispute resolution processes in Canada. If we are going to concern ourselves with the potential shortcomings of private dispute resolution processes, which I think we should (and which the new Ontario legislation does), then we should do so in a way that avoids casting our net too narrowly. By treating the Sharia debate as an element of the broader move largely to privatize the civil justice system, we are by no means in danger of throwing the baby out with the bathwater.

I recognize that the private resolution of disputes has occurred since the beginning of disputes themselves, and this is often a good thing. To the extent that it can avoid becoming involved, the state certainly does not need (or want) to interfere, for example, with two roommates negotiating over what movie to see, or how the phone bill should be shared. On the other hand, some disputes that occur in private should ideally be dealt with in public, or at least with public procedural safeguards regarding transparency, fairness, power, equality, etc. Disputes involving children or other vulnerable individuals are often examples of these sorts of disputes. Unfortunately, unless we are going to rewrite fundamental constitutional and privacy legislation and jurisprudence, the state is not going to get involved in all of those disputes either. To the extent that the state does come into play - either directly through its public court system or indirectly through courtannexed mediation, arbitration legislation, or government-sanctioned or encouraged dispute resolution procedures, etc. - it should take an active role in ensuring that it is not sanctioning human rights violations or other injustices. The new Ontario legislation admirably seeks 
to assist in this regard in terms of family disputes. But family arbitration is only the tip of the proverbial iceberg in terms of private, state-sanctioned dispute resolution processes involving important public interest values.

With respect to the sub-issue of public governance in a community, this is a procedural matter largely conducted through the institutions of legislation and adjudication. Clearly the decisions of public civil courts play an important normative role in our democratic processes. ${ }^{53}$ Likewise, private dispute resolution processes - through directapplication or indirect processes of behaviour modification - also have an impact upon the broader public community in which those private processes occur. As such, to the extent that we are privatizing our public civil dispute resolution system, we are essentially privatizing a significant part of the way we govern ourselves in a democratic society. There may be good reasons to pursue privatization, at least to a limited extent; however, the current trend of privatization - largely in the name of cost and efficiency - is being conducted without adequate public debate about, let alone public understanding of, those reasons. Whether or not family disputes - religious or otherwise should be privatized is just one element of that broader debate.

\section{Conclusion}

There are fundamental procedural and constitutional issues underlying the Ontario Sharia debate. The issues are of interest to people across the country and around the world. This debate must be framed clearly and accurately in order to foster and understand its informed and meaningful resolution, and also to understand and address the fundamental issues underlying the debate. Unfortunately, clarity and accuracy have not characterized the debate to-date, a failure that jeopardizes its proper understanding. This failure also potentially jeopardizes our understanding of the important underlying procedural and governance issues at play in the debate that are also at the heart of our democratic process. It is these issues, in my view, that - in the words of Atwood et al. quoted at the outset of this article - "han[g] in the balance. ${ }^{" 54}$ Reframing the Sharia debate will provide us with an opportunity to take a closer look at what we are doing not only to family law in Ontario, but also at adjudication as a form of governance in all parts of the country. This is an opportunity we should not pass up.

\section{Notes}

* Assistant Professor, Osgoode Hall Law School, York University, tfarrow@osgoode.yorku.ca. This article was originally presented at a public panel entitled: "Religious Tribunals: Civil and Constitutional Law Perspectives" (Centre for Constitutional Studies, University of Alberta, Edmonton, 1 November 2005). My initial views in this article benefited from discussions with Gerald Gall.

1 Margaret Atwood et al., "Don't ghettoize women's rights" Globe and Mail (10 September 2005) A23 [Atwood et al.], online: International Campaign against Shari'a Court in Canada <http://www. nosharia.com/OPEN\%20LETTER\%20TO\%20 ONTARIO\%20PREMIER\%20DALTON\%20 McGUINTY.htm>.

2 Sheema Khan, "The sharia debate deserves a proper hearing" Globe and Mail (15 September 2005) A21 [Khan].

3 Atwood et al., supra note 1.

4 Ibid.

5 Anver Emon, "A mistake to ban sharia” Globe and Mail (13 September 2005) A21 [Emon]. For a background summary of the debate, see Marion Boyd, "Dispute Resolution in Family Law: Protecting Choice, Promoting Inclusion" (December 2004) at 3-6, online: Ontario Ministry of The Attorney General <http://www. attorneygeneral.jus.gov.on.ca/english/about/pubs/ boyd/fullreport.pdf> [Boyd Report].

6 Family Statute Law Amendment Act, 2006, S.O. 2006, c. 1.

$7 \quad$ Many of these important issues are being specifically addressed elsewhere. See e.g. "Religious Tribunals: Civil and Constitutional Law Perspectives" (Panel discussion, Centre for Constitutional Studies, Edmonton, 1 November 2005) ["Religious Tribunals"]. In addition, see the Boyd Report, supra note 5.

8 See generally Boyd Report, ibid. at 4; Diana Lowe and Jonathan H. Davidson, "What's Old Is New Again: Aboriginal Dispute Resolution and the Civil Justice System” in Catherine Bell \& David 
Kahane, eds., Intercultural Dispute Resolution in Aboriginal Contexts (Vancouver: UBC Press, 2004) 280 at $286-88$.

9 Judy van Rhijn, "First steps taken for Islamic arbitration board" The Law Times (24 November 2003) 11. See generally Boyd Report, ibid at 3.

10 Boyd Report, ibid. at 5.

11 See ibid. For news commentaries and reactions to her report, see e.g. Keith Leslie, "Let Ontario families use Muslim law in disputes, report urges" Globe and Mail (21 December 2004) A12; Editorial, "Islamic arbitration, by the rules all follow" Globe and Mail (22 December 2004) A18; and Margaret Wente, "The state should not give its blessing to Muslim courts" Globe and Mail (23 December 2004) A23.

12 See e.g. Khan, supra note 2; Emon, supra note 5; and Marina Jiménez, "B’nai Brith recommends sharia-based tribunals" Globe and Mail (9 September 2004) A8.

13 See e.g. Atwood et al., supra note 1; Margaret Wente, "Whistling sharia while we go completely off our rocker" Globe and Mail (8 September 2005) A23 [Wente, "Whistling sharia"].

14 See e.g. Marina Jiménez, "Debate stirs hatred, sharia activists say" Globe and Mail (15 September 2005) A6; Marina Jiménez, "Sharia decision sparks Jewish protest" Globe and Mail (13 September 2005) A1 [Jiménez, "Sharia decision sparks Jewish protest”]; Editorial, "Of common values and the sharia fight" Globe and Mail (13 September 2005) A20; Marina Jiménez, "A Muslim woman's sharia ordeal" Globe and Mail (8 September 2005) A1; Canadian Council of Muslim Women, "Concerned about traditional religious interpretations" in "Shari'a arbitration proposal in Ontario hits New York Times' pages" 24:14 The Lawyers Weekly (August 2004) ["Sharia arbitration proposal in Ontario hits New York Times' pages"]; Lynda Hurst, "Ontario sharia tribunals assailed” Toronto Star (22 May 2004) A1; and Lynda Hurst, "Protest rises over Islamic law in Ontario" Toronto Star (8 June 2004) A4. See e.g. Mark Bourrie, "Still wiggle room for faith-based arbitration" Law Times (28 November 2005) 9 [Bourrie]; Sheldon Gordon, "Sacred Settlements" National (March 2005) 32 [Gordon]; Raj Anand, "Constitutional and Human Rights Issues in Religious Tribunals - Faith Based Arbitrations" (joint meeting of the Canadian Bar Association - Alberta Branch, Constitutional and Civil Liberties Section - Northern, and the Centre for Constitutional Studies, University of Alberta,
Edmonton, 20 September 2005) [Anand]; and Michelle C. Christopher, "Sharia Law in Canada" 29:2 Law Now (October 2004) 36.

16 See e.g. "Religious Tribunals," supra note 7; Ayelet Shachar, "Religion, State, and the Problem of Gender: New Modes of Citizenship and Governance in Diverse Societies" (2005) 50 McGill Law Journal 49; Annie Bunting \& Shadi Mokhtari, "Migrant Muslim Women's Interests and the Case of 'Shari'a Tribunals' in Ontario" in Vijay Agnew, ed., Migrant Women's Quest for Social Justice (forthcoming); Annie Bunting, "Mediating Cultures, Arbitrating Family Disputes - the Proposed 'Shari'a Tribunals' in Ontario" (November 2004 Draft), online: National Judicial Institute < http://nji.ca/nji/CCIAWJ/ papers/new/53_Bunting_Arbitrating_.pdf $>$; Natasha Bakht, "Family Arbitration Using Sharia Law: Examining Ontario's Arbitration Act and its Impact on Women" (2004) 1 Muslim World Journal of Human Rights, online: $<$ http://www.bepress.com/cgi/viewcontent. cgi ?article $=1022 \&$ context $=$ mwjhr $>$; Jean - François Gaudreault-Desbiens, "The Limits of Private Justice” Nexus (Fall/Winter 2004) 27; and Gerald Gall, "Religious tradition and Canadian law" The Canadian Jewish News (3 March 2005), online: <http://www.cjnews.com/viewarticle. asp?id=5575 $>$. See further Susan B. Boyd \& Claire F.L. Young, "Feminism, Law, and Public Policy: Family Feuds and Taxing Times" (2004) 42 Osgoode Hall Law Journal 545 at 582; Sonia N. Lawrence, "Cultural (in) Sensitivity: The Dangers of a Simplistic Approach to Culture in the Courtroom" (2001) 13 Canadian Journal of Women and the Law 107 at 134; and Yash Ghai, "Universalism and Relativism: Human Rights as a Framework for Negotiating Interethnic Claims" (1999-2000) 21 Cardozo Law Review 1095. For further background commentary, see Special Issue, "Islam and Human Rights Advocacy for Social Change in Local Contexts" (2005) 2 Muslim World Journal of Human Rights, online: Berkeley Electronic Press <http://www.bepress. com/mwjhr/vol2/>.

17 "Ontario Premier rejects use of Shariah law" CBC News (11 September 2005), online: CBC News <http://www.cbc.ca/story/canada/ national/2005/09/09/sharia-protests-20050909. html >; "McGuinty rules out use of sharia law in Ontario" CTV.ca (12 September 2005), online: <http://www.ctv.ca/servlet/ArticleNews/story/ CTVNews/1126472943217_26/?hub=TopStories $>$ ["McGuinty rules out use of sharia law in Ontario"]. 
18 "McGuinty rules out use of sharia law in Ontario," ibid.

19 Ibid.

20 Ibid.

21 See e.g. Canadian Charter of Rights and Freedoms, Part I of the Constitution Act, 1982, being Schedule B to the Canada Act 1982 (U.K.), 1982, c. 11 [Charter], ss. 2(a), 15, 27, and 28, as further discussed in Anand, supra note 15.

22 Ministry of the Attorney General, "Statement by Attorney General on the Arbitration Act 1991" (8 September 2005), online: Government of Ontario <http://ogov.newswire.ca/ontario/ GPOE/2005/09/08/c7547.html?lmatch=\&lang= e.html>.

23 Quoted in Jane Sims, "Boyd says ban on Shariah law won't end it: The former London MPP predicts religion-based arbitration will simply move 'underground"' The London Free Press (10 November 2005), online: Canadian Jewish Congress $<$ http://www.cjc.ca/template.php?action $=$ itn\&Story $=1556>$.

24 Quoted in Jiménez, "Sharia decision sparks Jewish protest," supra note 14 at A1. If this is right, as a practical matter, there are strong arguments for making room for regulated, state-sanctioned religious-based arbitrations (in the same way that there are strong arguments for legalizing a regulated form of state-sanctioned prostitution). Put simply, if Sharia arbitrations are going to happen, then we should at least try to make them as fair as possible. For support for this argument, see e.g. Boyd Report, supra note 5. For further discussion, see Bourrie, supra note 15.

25 S.O. 1991, c. 17, [Arbitration Act, 1991].

26 Ibid., s. 2(1)(a). For further comment, see Bourrie, supra note 15.

27 I have discussed these benefits elsewhere. See e.g. Trevor C.W. Farrow, "Privatizing Our Public Civil Justice System" (2006) 9 News \& Views on Civil Justice Reform 16 at 16, online: Canadian Forum on Civil Justice <http://www.cfcj-fcjc.org/issue_9/ CFCJ\%20(eng)\%20spring\%202006-Privatizing. pdf $>$ [Farrow, "Privatizing Our Public Civil Justice System"]; Trevor C.W. Farrow, "Dispute Resolution, Access to Civil Justice and Legal Education" (2005) 42 Alberta Law Review 741 at 746 [Farrow, "Dispute Resolution"].

28 Arbitration Act, 1991, supra note 25.

29 Ibid.s. 37.

30 Desputeaux v. Éditions Chouette (1987) inc., [2003] 1 S.C.R. 178, 2003 SCC 17 (CanLII)at para. 41.

31 Supra note 5.
32 Family Statute Law Amendment Act, supra note 6. A "family arbitration" is defined in s. 1 of the legislation to include an arbitration that "deals with matters that could be dealt with in a marriage contract, separation agreement, cohabitation agreement or paternity agreement..." and "is conducted exclusively in accordance with the law of Ontario or of another Canadian jurisdiction ...." Ibid.

33 For a discussion on this point, see Bourrie, supra note 15.

34 See further Farrow, "Privatizing Our Public Civil Justice System," supra note 27.

35 See International Campaign Against Shari'a Court in Canada Homepage, online: <http://www. nosharia.com/index.htm>. See further Wente, "Whistling sharia," supra note 13; Jiménez, "Sharia decision sparks Jewish protest," supra note 14 at A1.

36 Atwood et al., supra note 1. See further "Sharia arbitration proposal in Ontario hits New York Times' pages," supra note 14 .

37 Gordon, supra note 15 at 35.

38 For a useful international background source for Canadian and other international arbitral legislation, see Asia-Pacific Economic Conference, "A Guide to Arbitration and ADR in APEC Member Economies", online: <http://203.127.220.111/query. html?qt=Arbitration $>$. For a useful domestic background summary, see Julie Macfarlane, gen. ed. et al., Dispute Resolution: Readings and Case Studies, $2 \mathrm{~d}$ ed. (Toronto: Emond Montgomery, 2003) 622-25 [Macfarlane].

39 See Norma Greenaway, "63 percent oppose faithbased arbitration" The Ottawa Citizen (31 October 2005), online: <http://www.canada.com/ottawa/ ottawacitizen/soundoff/story.html?id=997485b8bf66-41a1-bd58-8b8e1e434193>.

40 Sheila Pratt, "Muslim religious tribunals to settle family disputes a regressive step" Edmonton Journal (26 September 2005), online: Canadian Council of Muslim Women $<$ http://www.ccmw. com/MuslimFamilyLaw/Muslim\%20religious $\% 20$ tribunal\%20to\%20settle\%20family\%20di sputes\%20a\%20regressive\%20step.htm>. The issue of religious-based tribunals was, however, actively discussed in Alberta both at a September 2005 Canadian Bar Association - Alberta Constitutional and Civil Liberties Law Section meeting (see Anand, supra note 15) and again at "Religious Tribunals," supra note 7.

41 Arbitration Act, R.S.A. 2000, c. A-43. Specifically, see e.g. ss. 2, 6, 44-45. 
42 CBC News, "No religious-based law for B.C., says AG” CBC.ca (8 September 2004), online: CBC British Columbia <http://www.cbc.ca/bc/story/ bc_shariah20040908.html $>$.

43 See e.g. "Vancouver Sun reports some local interest in formally introducing Islamic sharia law to family disputes in BC: No official word from BC Muslim Association on issue" (updated 9 September 2004), online: JP Boyd's British Columbia Family Law Resource <http://www. bcfamilylawresource.com/20/2004body. htm\#0053>.

44 See Commercial Arbitration Act, R.S.B.C. 1996, c. 55, s. 2. But see ibid. at s. 2(2). For a discussion of family arbitration in B.C., see Catherine Morris, "Arbitration of Family Law Disputes in British Columbia: Paper prepared for the Ministry of Attorney General of British Columbia" (7 July 2004), online: <http://www.bcjusticereview.org/ working_groups/family_justice/paper_07_07_ 04.pdf>.

45 Uniform Law Conference of Canada, Uniform Arbitration Act, online: <http://www.ulcc.ca/en/ us/arbitrat.pdf>.

46 See e.g. the various arbitration statutes in Saskatchewan, Manitoba, New Brunswick and Nova Scotia. For a useful collection and discussion of Canadian arbitration legislation, see Wendy J. Earle, Drafting ADR and Arbitration Clauses for Commercial Contracts, looseleaf (Toronto: Thomson Carswell, 2001). See further Natasha Bakht, "Arbitration, Religion and Family Law: Private Justice on the Backs of Women" (March 2005), online: Law Commission of Canada <http://www.lcc.gc.ca/research_project/ bakht_main-en.asp $>$.

47 Because this third concern is the subject of my broader, ongoing research examining current trends of privatization in our civil justice system, I only briefly introduce and develop my concerns here. For further discussion of these ideas, see e.g. Farrow, "Privatizing Our Public Civil Justice System," supra note 27; Farrow, "Dispute Resolution," supra note 27 at 797, n. 365.

48 Atwood, et al., supra note 1.

49 For a general discussion of these initiatives, see Farrow, "Privatizing Our Public Civil Justice System," supra note 27; Farrow, "Dispute Resolution," supra note 27 at 741-54.

50 For comments on judicial activism, including from Canadian judges themselves, see Kirk Makin, "Judicial activism has gone too far, court says" Globe and Mail (12 December 2002) A1, online: <http://www.fact.on.ca/news/news0212/ gm021212.htm>; Kirk Makin, "Attack on judiciary shatters strategic silence" Globe and Mail (10 May 2006) A5. Compare Kirk Makin, "Judicial activism debate on decline" Globe and Mail (8 January 2005).

51 Atwood et al., supra note 1.

52 See Farrow, "Privatizing Our Public Civil Justice System," supra note 27; Farrow, "Dispute Resolution," supra note 27 at 797-98. See further Carrie Menkel-Meadow, "Whose Dispute Is It Anyway?: A Philosophical and Democratic Defense of Settlement (In Some Cases)" (1995) 83 Georgetown Law Journal 2663, discussed in Macfarlane, supra note 38 at 619-20.

53 See e.g. Owen Fiss, “The Forms of Justice” (1979) 93 Harvard Law Review 1, reprinted in Owen Fiss, The Law as It Could Be (New York: New York University Press, 2003) 1; Owen Fiss, "Against Settlement” (1984) 93 Yale Law Journal 1073, reprinted in The Law as It Could Be at 90; and David Luban, "Settlements and the Erosion of the Public Realm" (1995) 83 Georgetown Law Journal 2619. For a collection and discussion of these and other materials on this issue, see Macfarlane, ibid at 615-20.

54 Atwood et al., supra note 1. 